\title{
Penerapan Model RESPECTFUL dalam Pembelajaran Berasaskan Permainan Digital bagi Kursus Kaunseling Pelbagai Budaya
}

\author{
Application of the RESPECTFUL Model in Digital Game Based Learning \\ for Multicultural Counseling Courses
}

\author{
Nur Fasiha Samsu Zaman@ @aufiq1, Nur Azimah Khairulamin², \\ Laili Farhana Md Ibharim ${ }^{3}$ \\ ${ }^{1}$ Universiti Pendidikan Sultan Idris; fasihataufiq@gmail.com \\ ${ }^{2}$ Universiti Pendidikan Sultan Idris; azimahkhairul94@gmail.com \\ ${ }^{3}$ Universiti Pendidikan Sultan Idris; laili@fskik.upsi.edu.my
}

DOI: https://doi.org/10.37134/jictie.vol7.1.1.2020

\begin{abstract}
Abstrak
Bagi mengatasi cabaran pendidik untuk menghasilkan generasi muda yang mempunyai fikiran aras tinggi, berdaya saing, dan kompeten dalam pendidikan berteraskan teknologi, bidang pendidikan memerlukan lebih banyak inovasi. Kertas konsep ini membincangkan tentang pembelajaran berasaskan permainan dalam kursus Kaunseling Pelbagai Budaya menggunakan model RESPECTFUL. Objektif kertas konsep ini ialah untuk membina sebuah kerangka konsep bagi pembangunan aplikasi permainan yang akan digunakan oleh kaunselor pelatih sebagai alat bantu belajar. Kajian perpustakaan telah dilakukan dan artikel serta jurnal telah dianalisis bagi mendapatkan rujukan yang berkaitan. Sebuah kerangka konsep telah dicadangkan bagi membina sebuah aplikasi permainan yang akan digunakan oleh kaunselor pelatih sebagai alat bantu belajar untuk mengetahui tahap penerimaan terhadap bakal klien yang datang daripada pelbagai kelompok budaya yang unik.
\end{abstract}

Kata Kunci: pembelajaran berasaskan permainan digital, kaunseling pelbagai budaya, Model Respectful

\begin{abstract}
To address the challenge of educating young, high-performing, competitive and competent young people in technology-based education, the field of education requires more innovation. This concept paper discusses game-based learning in the Multicultural Counselling course using the RESPECTFUL model. The objective of this concept paper is to develop a conceptual framework for the development of game applications that will be used by the coaching counsellor as a learning aid. Library studies were conducted, and articles and journals were analysed to obtain relevant references. A conceptual framework has been proposed to develop a game application that will be used by the coaching counsellor as a learning tool to determine the level of acceptance of potential clients coming from a variety of unique cultural groups.
\end{abstract}

Keywords: digital game-based learning, multicultural counseling, Respectful Model 


\section{PENGENALAN}

Dunia pada hari ini memerlukan generasi yang kompeten dan berdaya saing bagi menerima perubahan teknologi yang semakin berkembang pesat sejajar dengan sistem pendidikan negara. Perkembangan dalam bidang pendidikan haruslah dititikberat agar kualiti pendidikan terjamin dan berupaya dalam menghasilkan generasi muda yang mempunyai kemahiran berfikir aras tinggi memandangkan mereka adalah aset penting dalam pembangunan negara. Menurut Wong dan Osman (2018), transformasi di dalam bidang pendidikan seharusnya berlaku seiring dengan arus pemodenan dunia, terutamanya dalam pengajaran dan pemudahcaraan $(\mathrm{PdPc})$. Menurutnya lagi, di dalam proses PdPc, alatan elektronik seperti internet dan komputer merupakan salah satu alat yang digunakan oleh pendidik di Malaysia. Alat ini bukan sahaja merupakan alat bantu mengajar di dalam kelas tetapi juga merupakan satu alat kepada pelajar untuk mengakses dan mencari maklumat. Perkembangan di dalam pendidikan dunia dapat dilihat dengan ketara apabila terhasilnya pendidikan yang berteraskan teknologi. Teknologi dilihat berjaya mendepani teknik konvensional di dalam pengajaran dan pembelajaran apabila banyak usaha-usaha telah dibuat untuk menghasilkan teknik pedagogi yang berkait rapat dengan teknologi. Oleh yang demikian, antara cabaran pendidik pada abad ini ialah bagaimana untuk menghasilkan generasi muda yang mempunyai fikiran aras tinggi, berdaya saing, dan kompeten dengan mengaplikasikan teknologi di dalam pendidikan.

Dalam usaha menghasilkan modal insan yang kompeten dalam mengaplikasikan teknologi dalam pendidikan, pembelajaran berasaskan permainan telah diperkenalkan. Kajian-kajian yang berkaitan dengan pembelajaran berasaskan permainan telah banyak dilakukan, antaranya ialah pembelajaran berasaskan permainan yang meliputi subjek STEM iaitu Sains, Teknologi, Engineering dan Matematik. Wong dan Osman (2018) di dalam kajiannya menyatakan bahawa dalam kajian yang menggunakan pembelajaran berasaskan permainan, telah banyak kajian yang menggunakan permainan pendidikan sebagai alat bantu belajar. Kajian tersebut menunjukkan bahawa permainan digital membantu dalam penguasaan konsep dan motivasi pelajar. Namun begitu, walaupun terdapat banyak kajian pembelajaran berasaskan permainan dengan subjek STEM telah dijalankan, kajian tentang permainan pendidikan di dalam subjek Kaunseling Pelbagai Budaya masih kurang dijalankan dan tidak mendapat perhatian sewajarnya.

Kaunseling merupakan perkara yang tidak asing lagi di dalam kehidupan masa kini. Keupayaan kaunseling untuk mengubah personaliti individu menunjukkan bahawa kewujudan kaunseling adalah penting dalam usaha untuk melahirkan generasi yang sihat dari segi mental dan rohani. Namun begitu, bagi melahirkan kaunselor yang mempunyai pengetahuan dan pengalaman dalam bidang kaunseling, kaunselor pelatih haruslah diberi pendedahan yang secukupnya sebelum dibenarkan menjadi kaunselor terlatih.

Dalam usaha melahirkan kaunselor profesional yang dapat menghadapi klien, kaunselor pelatih yang mengambil jurusan Kaunseling di universiti seharusnya diberikan pendedahan awal tentang bagaimana untuk mengenali diri mereka sendiri terlebih dahulu. Hal ini bagi memastikan kaunselor tidak 
mencampur-adukkan hal peribadi serta tidak bersikap diskriminasi dalam menjalankan tugas.

Oleh itu, objektif yang ingin dicapai di dalam kertas konsep ini ialah untuk membina kerangka konsep yang akan digunakan dalam pembinaan sebuah permainan digital yang bakal digunakan oleh kaunselor pelatih sebagai alat bantu belajar di dalam kursus Kaunseling Pelbagai Budaya.

\section{TINJAUAN LITERATUR}

\section{Pembelajaran Berasaskan Permainan}

Seiring dengan kemajuan teknologi pada abad ini, transformasi yang menggabungkan teknologi di dalam pendidikan amatlah diperlukan. Menurut Nurfazliah et al., (2018), antara teknologi yang sepadan dengan pengajaran ialah teknologi yang interaktif serta dapat menarik minat pelajar. Menurut Osman dan Wong (2018), permainan boleh dibahagikan kepada dua, iaitu permainan digital dan bukan digital. Dalam kajian Nazirah Mat Sin et al. (2013) pula, permainan bertujuan untuk hiburan sahaja manakala pembelajaran berasaskan permainan digital pula bertujuan untuk memupuk kecekapan dan meningkatkan ilmu kepada pemain dan pelajar.

Pembelajaran berasaskan permainan menurut Osman (2015) ialah merupakan satu platform pembelajaran di mana pelajar ialah pemain dan dalam pada masa yang sama juga merupakan pereka cipta permainan digital dalam mempelajari Kimia. Liu dan Chen (2013) pula menegaskan bahawa pembelajaran berasaskan permainan merujuk kepada permainan kad dalam mempelajari subjek Sains. Permainan kad tersebut dapat meningkatkan hubungan interpersonal dalam proses pembelajaran. Sayed Yusoff, Tan, dan Muhammad Zaffwan (2013) menyatakan permainan digital sebagai media pembelajaran yang sesuai untuk semua mata pelajaran yang diajar di peringkat pra sekolah, sekolah rendah dan sekolah menengah. Menurut Sayed Yusoff et al. (2013) lagi, permainan digital yang menggabungkan konsep pendidikan dengan hiburan juga dilihat sebagai satu inovasi baru, dan mungkin membuatkan pelajar terhibur semasa proses pembelajaran. Dalam kertas konsep ini, pembelajaran berasaskan permainan dgital merujuk kepada permainan digital yang menggunakan model RESPECTFUL di dalam kursus Kaunseling Pelbagai Budaya sebagai alat bantu belajar atau instrument untuk mengukur tahap penerimaan kaunselor pelatih terhadap klien yang datang daripada pelbagai kumpulan budaya yang unik.

Kajian-kajian lepas menunjukkan bahawa pembelajaran berasaskan permainan merupakan gabungan pendidikan dengan permainan sebagai salah satu proses pembelajaran. Terdapat beberapa kajian yang menegaskan bahawa pembelajaran berasaskan permainan dapat meningkatkan pencapaian pelajar (Sung \& Hwang, 2013). Selain itu, pembelajaran berasaskan permainan juga memberikan keseronokan kepada pelajar semasa proses pembelajaran sedang berlaku. (Sayed Yusoff et al., 2013). Menurut Nurfazliah et al. (2018) pula, penggunaan permainan digital atau pembelajaran berasaskan permainan merupakan satu cara yang bertepatan dalam meningkatkan kemahiran penyelesaian masalah dalam 
pembelajaran. Ini jelas menunjukkan bahawa selain dapat meningkatkan pencapaian pelajar, pembelajaran berasaskan permainan juga dapat memberikan keseronokan semasa proses pembelajaran sedang berlangsung dan dapat meningkatkan kemahiran menyelesaikan masalah dalam kalangan pelajar.

Menurut Sung dan Hwang (2013), permainan komputer pendidikan kolaboratif di dalam subjek Sains dapat membantu pelajar dalam meningkatkan pencapaian mereka berbanding dengan pelajar yang menggunakan pendidikan berasaskan permainan kolaboratif konvensional. Selain itu juga, permainan komputer pendidikan kolaboratif juga berjaya meningkatkan sikap serta motivasi pelajar dalam proses pembelajaran subjek Sains. Penyataan ini disokong oleh Bayir (2014) yang menegaskan bahawa pembelajaran dalam permainan subjek Kimia menyediakan cara yang menghiburkan pelajar bagi memudahkan pelajar dalam proses pembelajaran unsur-unsur, sebatian, dan jadual berkala. Menurutnya lagi, bermain permainan tersebut juga membantu pelajar mengukuhkan konsep kimia yang telah dipelajari.

Dalam pembelajaran berasaskan permainan, terdapat dua teori yang digunakan, iaitu teori kognitif dan teori konstruktivis. Kajian-kajian lepas menunjukkan bahawa teori pembelajaran kognitif dan teori konstruktivis merupakan antara teori yang banyak digunakan dalam kajian yang mengaitkan pembelajaran dengan pengalaman hidup. Kognitif ialah sebuah proses aktif dan kreatif yang bertujuan membina struktur melalui pengalaman. Menurut Baharuddin dan Hassan (2015), teori pembelajaran kognitif mementingkan proses belajar daripada hasil belajar. Teori ini juga menekankan bahawa reaksi atau perbuatan seseorang ditentukan oleh persepsi serta pemahamannya tentang situasi yang berhubungan dengan tujuan belajarnya. Menurutnya lagi, model belajar kognitif merupakan suatu bentuk teori belajar yang sering disebut sebagai model perseptual. Justeru itu, proses belajar ialah merupakan perubahan persepsi dan pengalaman yang tidak selalu dapat dilihat sebagai tingkah laku yang kelihatan. Hal ini turut disokong oleh Miswandi et al, (2017) yang mengatakan bahawa bahawa pembelajaran kognitif adalah gambaran dari apa yang pelajar telah pelajari ketika melakukan proses pembelajaran.

Menurut Osman dan Wong (2018), teori konstruktivis menganggap bahawa pelajar meneroka sesuatu ilmu yang baru berdasarkan kepada pengalaman seharian mereka ataupun ilmu yang telah dipelajari sebelumnya. Baharuddin dan Hassan (2015) pula berkata konstruktivis merupakan sebuah falsafah pembelajaran yang dianggap dengan merefleksikan pengalaman, pelajar dapat membangun serta membina pengetahuan pengalaman tentang dunia tempat mereka hidup. Tambahannya lagi, konstruktivis melandaskan pemikirannya bahawa pengetahuan bukanlah sesuatu yang given dari alam kerana hasil hubungan manusia dengan alam, tetapi pengetahuan merupakan hasil pembinaan (bentukan) aktif manusia itu sendiri. Justeru, Nam dan Osman (2017) menegaskan pelajar akan menghuraikan serta melakukan hubungkait ilmu yang baru dipelajari dengan ilmu yang sedia ada di dalam diri pelajar semasa proses pembelajaran sedang berlaku. Setelah itu, pelajar akan mempersembahkan ilmu baru tersebut mengikut apa yang telah difahami mereka. 


\section{Model RESPECTFUL dalam Kursus Kaunseling Pelbagai Budaya}

Demi melahirkan generasi yang kompeten dan berdaya saing, pelbagai usaha telah dilakukan oleh kerajaan dalam memastikan penghasilan generasi yang berkualiti. Menurut Falsafah Pendidikan Kebangsaan, pendidikan di Malaysia adalah suatu usaha berterusan ke arah memperkembangkan lagi potensi individu secara menyeluruh dan bersepadu untuk mewujudkan insan yang seimbang dan harmonis dari segi intelek, rohani, emosi dan jasmani berdasarkan kepercayaan dan kepatuhan kepada Tuhan. Falsafah Pendidikan Kebangsaan juga menegaskan bahawa usaha ini adalah bagi melahirkan rakyat Malaysia yang berilmu pengetahuan, berketerampilan, berakhlak mulia, bertanggungjawab dan berkeupayaan mencapai kesejahteraan diri, serta memberi sumbangan terhadap keharmonian dan kemakmuran keluarga, masyarakat dan negara. Oleh itu, antara agensi penting yang terlibat dalam penghasilan generasi yang seimbang dari segi intelek, rohani, emosi dan jasmani ialah kaunseling seperti yang dinyatakan oleh Tratler dan North (1966) dalam penulisan Abdul Halim Othman (2009) iaitu kaunseling merupakan hubungan interpersonal antara dua individu iaitu kaunselor dan klien.

Menurut Aida Nubaillah et al. (2018), Kementerian Pendidikan Malaysia (KPM) telah menguatkuasakan pelantikan guru bimbingan dan kaunseling di sekolah untuk memainkan peranan penting sebagai agen perubahan dalam aspek pembangunan modal insan untuk membangunkan agenda pembangunan negara. Menurutnya lagi, keperluan perkhidmatan bimbingan dan kaunseling di Malaysia semakin mendapat tempat dan meliputi semua lapisan masyarakat terutamanya dari segi perubahan sosial yang unik yang menyentuh kepada perubahan budaya dan cara hidup masyarakat. Kaunseling pelbagai budaya yang menekankan aspek nilai, kepercayaan, sikap, dan tingkah laku yang dimiliki oleh kelompok masyarakat menjadikan bidang ini amat penting memandangkan Malaysia merupakan sebuah negara yang berbilang bangsa dan agama. Oleh yang demikian, memandangkan profesion kaunselor menjadi satu keperluan signifikan kepada masyarakat, adalah penting bagi institusi-institusi awam atau swasta di negara untuk berusaha menghasilkan kaunselor yang pakar dan terlatih supaya dapat menjalankan tugas dengan baik. Namun begitu, bagi melahirkan masyarakat dan generasi yang kompeten dari segi rohani, intelek, jasmani, dan mental, penghasilan kaunselor pelatih haruslah diberikan perhatian yang sewajarnya.

Rajah 1 menunjukkan model RESPECTFUL (D’Andrea \& Daniels, 1997; 2001) yang terdiri daripada $\mathrm{R}=$ agama, $\mathrm{E}=$ latar belakang kelas ekonomi, $\mathrm{S}=$ identiti seksual, $\mathrm{P}=$ kematangan psikologi, $\mathrm{E}=$ identity bangsa dan etnik, $\mathrm{C}=$ kronologi/cabaran perkembangan, $\mathrm{T}=$ trauma, $\mathrm{F}=$ sejarah dan latar belakang keluarga, $\mathrm{U}=$ ciri-ciri fizikal yang unik, $\mathrm{L}=$ lokasi tempat tinggal dan perbezaan bahasa ialah satu model yang amat berguna bagi mengukur tahap penerimaan kaunselor terhadap klien yang datang dari pelbagai kelompok serta budaya yang unik. Kod Etika Kaunselor Lembaga Kaunselor Malaysia menegaskan bahawa kaunselor mestilah memahami dan menghormati latarbelakang dan budaya klien mereka. Kaunselor yang professional juga seharusnya tidak menunjukkan sebarang sikap diskriminasi terhadap klien masing-masing. Oleh yang demikian, bagi melahirkan dan mendidik kaunselor yang profesional, kaunselor terlebih dahulu haruslah mengenalpasti sebarang kemungkinan untuk bersikap diskriminasi atau bias dalam apa jua faktor yang mungkin wujud di dalam diri mereka dalam keadaan 
sedar atau pun tidak sedar. Oleh itu, kemungkinan kewujudan sikap diskriminasi dalam diri kaunselor pelatih dapat dilihat dengan menggunakan model RESPECTFUL.

\section{Model RESPECTFUL}

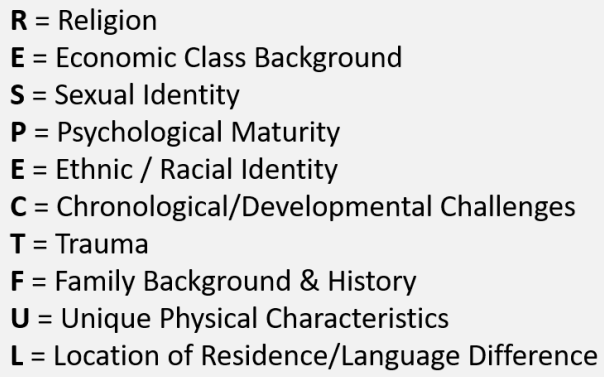

Rajah 1: Model RESPECTFUL

(D’Andrea \& Daniels, 1997; 2001)

Menurut Ivey, D'Andrea, Ivey dan Simek-Morgan (2002), model RESPECTFUL mempengaruhi cara individu belajar untuk mengenalpasti diri mereka dan orang lain. Menurutnya lagi, setiap faktor di dalam model tersebut memberi kesan kepada klien dan pengamal kesihatan mental dalam mengolah maksud tersurat dan tersirat daripada pelbagai cabaran dan masalah yang dihadapi klien. Faktor seperti agama amat perlu dititikberatkan oleh kaunselor dalam menghadapi klien mereka memandangkan negara Malaysia terdiri daripada pelbagai rakyat yang menganuti pelbagai agama dan bangsa. Ini menunjukkan bahawa model RESPECTFUL yang merangkumi 10 faktor tersebut amat sesuai untuk dijadikan asas dalam pembangunan alat bantu belajar bagi mengetahui tahap penerimaan kaunselor pelatih terhadap budaya klien yang unik.

\section{KERANGKA KONSEP BAGI PEMBINAAN APLIKASI PERMAINAN DIGITAL UNTUK KAUNSELOR PELATIH}

Pembelajaran berasaskan permainan semakin mendapat tempat dalam kalangan pendidik. Meskipun kajian tentang pembelajaran berasaskan permainan telah banyak dijalankan, namun kajian yang melibatkan kaunseling masih kurang mendapat perhatian. Kebanyakan kaunselor biasanya mengamalkan pendekatan tatap muka atau pendekatan secara tradisional apabila berhadapan dengan klien mereka. Kaunselor tidak mempunyai pendedahan tentang teknologi atau lebih tepat lagi pendekatan pembelajaran berasaskan permainan yang berkaitan dengan bidang kaunseling. Hal ini mungkin terjadi kerana kaunselor tidak arif tentang bagaimana permainan digital boleh digunakan 
dalam meneroka isu-isu klien terhadap latar budaya klien yang unik. Oleh yang demikian, teknologi di dalam bidang kaunseling merupakan satu topik yang agak baru dan masih kurang kajian dijalankan membabitkan kedua-dua isu ini.

Bagi mencapai objektif kertas konsep ini, satu kerangka konsep telah dicadangkan bagi membina sebuah permainan digital yang akan digunakan oleh kaunselor pelatih sebagai alat bantu belajar untuk mengetahui tahap penerimaan mereka terhadap bakal klien yang datang daripada pelbagai kelompok budaya. Rajah 2 menunjukkan contoh kerangka konsep tersebut.
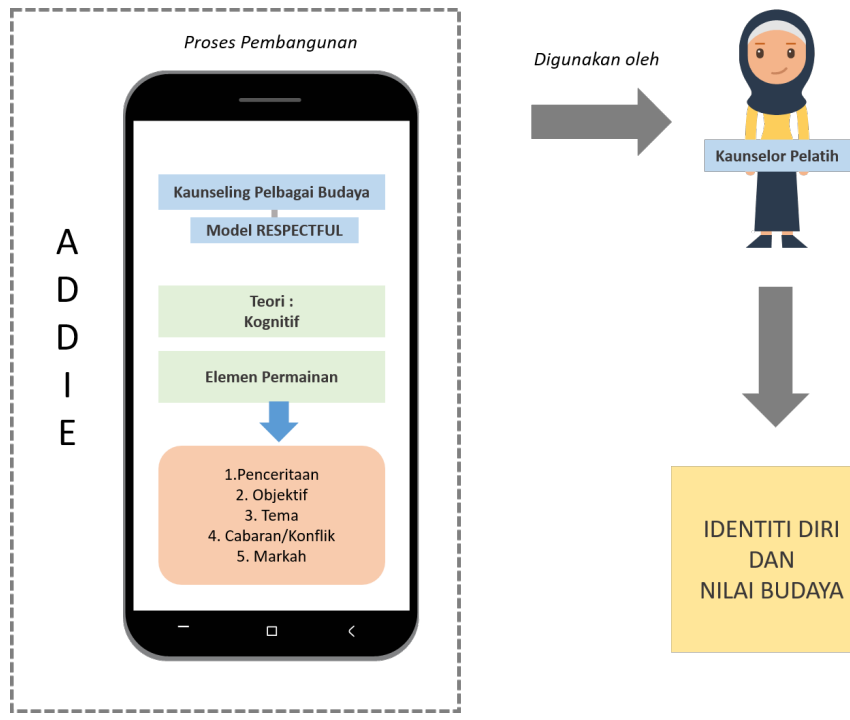

Rajah 2: Kerangka Konsep Pembelajaran Berasaskan Permainan dalam Kursus Kaunseling Pelbagai Budaya

Kerangka konsep di atas menunjukkan elemen-elemen dan hubungan elemen tersebut antara satu sama lain. Aplikasi permainan digital yang akan dibina adalah berdasarkan model RESPECTFUL yang menjadi bimbingan kepada kaunselor pelatih sebagai persediaan sebelum mereka berhadapan dengan klien yang sebenar. Oleh itu, elemen yang penting di dalam kerangka konsep ini ialah model ADDIE yang akan digunakan dalam pembangunan aplikasi, model RESPECTFUL di dalam kursus Kaunseling Pelbagai Budaya, teori yang digunakan iaitu teori kognitif, elemen permainan, serta kaunselor pelatih sebagai pengguna aplikasi.

\section{KESIMPULAN}

Pembelajaran berasaskan permainan ternyata memberikan kesan yang lebih baik di dalam pendidikan berbanding dengan kaedah konvensional. Pembelajaran berasaskan permainan dilihat dapat 
meningkatkan pencapaian pelajar, memberikan keseronokan kepada pelajar, dan meningkatkan sikap serta motivasi pelajar. Hal ini jelas menunjukkan bahawa menggunakan elemen permainan di dalam pendidikan merupakan satu langkah yang tepat. Namun begitu, pembelajaran berasaskan permainan di dalam bidang kaunseling masih belum mendapat perhatian baik daripada kaunselor mahu pun daripada para pendidik. Justeru, kerangka konsep yang dicadang diharapkan dapat menyumbang kepada pembinaan aplikasi permainan khas untuk kaunselor pelatih bagi mengetahui tahap penerimaan mereka terhadap nilai budaya klien yang pelbagai dan unik. Aplikasi permainan tersebut juga diharap dapat menyumbang kepada pemahaman kaunselor pelatih terhadap bagaimana model RESPECTFUL dapat membantu meneroka isu-isu yang terdapat dalam diri para klien.

\section{RUJUKAN}

Abdul Halim Othman. (2009). Kaunseling Untuk Kesejahteraan - Satu Kajian Kes Perkhidmatan Kaunseling di Universiti Kebangsaan Malaysia. Jurnal Personalia Pelajar, 12, 1-17.

Aida Nubaillah Noor, Salleh Amat, \& Abu Yazid Abu Bakar. (2018). Efikasi Kendiri Kaunseling dan Kecekapan Kaunseling Pelbagai Budaya dalam Kalangan Guru Bimbingan dan Kaunseling Sekolah Menengah di Malaysia. Jurnal Psikoedukasi dan Konseling, 2(2), 14-21.

Bayir, E. (2014). Developing and playing chemistry games to learn about elements, compounds, and the periodic table: Elemental Periodica, Compoundica, and Groupica. Journal of Chemical Education, 91(4), 531-535.

Dr. Baharuddin Ahmad \& Dr. Hassan Noor. (2015). Pengajaran \& Pembelajaran Dalam Pendidikan. Kuala Lumpur, Malaysia: SAM Synergy Media Sdn Bhd.

Ivey, A. E., D’Andrea, M., Ivey, M.B., \& Simek-Morgan,L. (2002). Theories of Counseling and Psychotheraphy: A Multicultural Perspectives (5th Edition). Boston : Allyn \& Bacon.

Liu, E.Z.F., \& Chen, P.-K. (2013). The Effect of Game- Based Learning on Students' Learning Performance in Science Learning - A Case of "Conveyance Go." Procedia - Social and Behavioral Sciences, 103, 1044-1051.

Miswandi Tendrita, Susriyati Mahanal, \& Siti Zubaidah. (2017). Pembelajaran Reading-Concept-Map Think Pair Share (REMAPS TPS) Dapat Meningkatkan Hasil Belajar Kognitif. Jurnal Pendidikan, 2(6), 763-767.

Nam,L. \& Osman. (2017). Developing 21st Century Skills through a Constructivist-Constructivist Learning Environment. $K-12$ STEM Education, 3(2), 205-216.

Nazirah Mat Sin, Othman Talib, \& Tengku Putri Norishah. (2013). Merging of game principles and learning strategy using apps for science subjects to enhance student interest and understanding. Jurnal Teknologi (Sciences and Engineering), 63(2), 7-12.

Nurfazliah Muhamad, Megat Aman Zahiri Megat Zakaria, Shaharudin Md. Salleh, \& Jamalludin Harun. (2018). Penggunaan Permainan Digital dalam Pembelajaran Bilik Darjah Bagi Meningkatkan Kreativiti Dalam Penyelesaian Masalah Matematik. Sains Humanika, 10:3-2, 39-45

Osman, K. (2015). Students as Digital Game Designers: Addressing the 21st Century Chemistry Education Needs in Malaysia. The 1st International Seminar on Chemical Education, 1, 6-15.

Sayed Yusoff Syed Hussain, Tan Wee Hoe, Muhammad Zaffwan Idris. (2013). Permainan Digital: Pendekatan Baharu Dalam Pendidikan Masa Depan. Prosiding Seminar Kebangsaan ICT Dalam Pendidikan, 240-245.

Siong, W.W., \& Osman, K. (2018). Pembelajaran Berasaskan Permainan dalam Pendidikan STEM dan Penguasaan Kemahiran Abad Ke-21. Politeknik \& Kolej Komuniti Journal of Social Sciences and Humanities, 3(1), 121-135

Sung, H.-Y., \& Hwang, G.-J. (2013). A collaborative game-based learning approach to improving students' learning performance in sciences courses. Computers \& Education, 63, 43-51. 